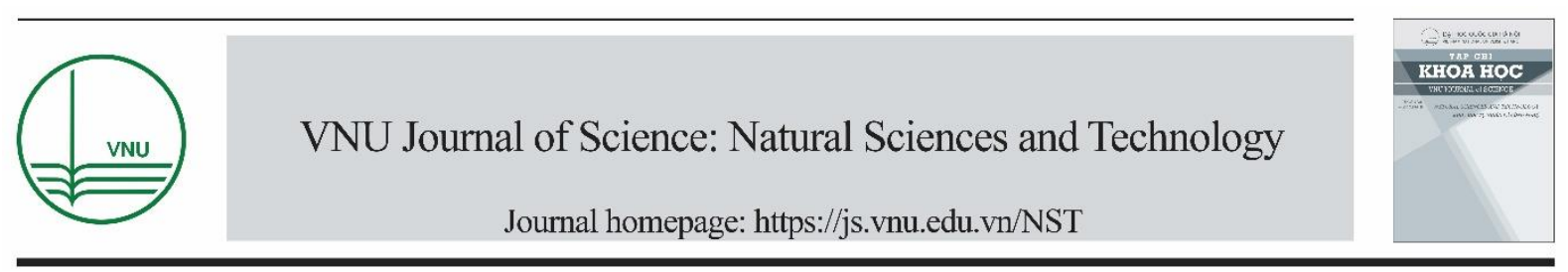

\title{
Preparation of Agarose-glucan Protein Drug Delivery for Anti-tumor Necrosis Factor
}

\author{
Nguyen Bao Ngoc ${ }^{1,2}$, Do Thi Ly ${ }^{1,2}$, Esther Derouet ${ }^{3}$, Nguyen Huu Tuan Dung ${ }^{1,2}$, \\ Nguyen Thanh Tung ${ }^{1,2}$, Nguyen Thi Phuong Linh ${ }^{1,2}$, Nguyen Hoang Nam ${ }^{4}$, Nguyen \\ Minh Hieu ${ }^{4}$, Nguyen Dinh Thang ${ }^{1}$, Nguyen Thi Van Anh ${ }^{1}$, Pham Thi Thu Huong 1,* \\ ${ }^{1}$ Key Laboratory of Enzyme and Protein Technology, VNU University of Science, \\ 334 Nguyen Trai, Hanoi, Vietnam \\ ${ }^{2}$ Faculty of Biology, VNU University of Science, 334 Nguyen Trai, Hanoi, Vietnam \\ ${ }^{3}$ Material Science Department, Polytech Lille, Lille 1 University, France \\ ${ }^{4}$ Nano and Energy Research Centre, VNU University of Science, 334 Nguyen Trai, Hanoi, Vietnam
}

Received 19 June 2018

Revised 30 November 2018; Accepted 03 December 2018

\begin{abstract}
This research aims to develop and characterize a protein drug delivery system in agarose-glucan complex. The complex was produced by sonicating the mixture of agarose-glucan components and a protein in liquid paraffin with Sonics Vibracell Processor adapted from the method of Nuo Wang et all 1997. Etanercept, an anti-tumor necrosis factor-alpha (anti-TNF- $\alpha$ ), was used as a model protein drug which was successfully encapsulated into agarose-glucan complex system. This protein can neutralize the TNF- $\alpha$, a pro-inflammatory cytokine that plays a pivotal role in regulating the inflammatory response in rheumatoid arthritis (RA) and is wellknown as mediator worsening RA pathogenesis. The prepared agarose-glucan complex possesses a range of sizes, from 30 to $150 \mathrm{~nm}$, dissolves well within the range of $\mathrm{pH}$ buffer from 5.2 to 6.2 with an average protein encapsulating efficiency up to $74.4 \%$, and can release up to $50 \%$ of protein after 40.3 hours. This research is the basis for developing nanogel-sized targeted drug delivery in RA treatment.
\end{abstract}

Keywords: Agarose gel, agarose microspheres, glucan, emulsification cooling, rheumatoid arthritis.

\section{Introduction}

Many drugs as proteins is attracting more and

\footnotetext{
${ }^{*}$ Corresponding author:Tel: 84-988429982.

Email: pthuongibt@gmail.com

https://doi.org/10.25073/2588-1140/vnunst.4758
}

more attention due to their high pharmacological potency but they remain some side effects. Therefore, the research about protein drug delivery systems has become important and necessary for certain cases. The use of protein drug delivery system helps to improve some limitations of using protein drug alone, such as poor targeting capability; high 
dosage of protein drug leading side effect and high cost for patients, etc.

Agarose, a kind of straight-chain polysaccharide which was used in this study has numerous applications for medical purpose including: Separation of biomolecules for analysis; Scaffolds for tissue engineering; Vehicle for drug delivery; Actuators for optics and fluidics; and Model extracellular matrices for biological studies [1-3]. Up on being dissolved in boiling water, agarose creates reversible hydrogel that can become a great vehicle to trap various types of components from organic compounds to proteins. The gelation characteristics created by the presence of hydrogen bonds can be destroyed by any factor lead to the destruction of hydrogen bonds. The pore size of agarose could be changed by the concentration of agarose. During dissolving in boiling water, agarose create reversible hydrogel. Hydrogels are hydrophilic polymeric materials that can absorb water without dissolving. The matrix created by agarose can become a great vehicle to trap various types of components from organic compounds to proteins. There have been several studies using agarose to produce microgel, nanogel incorporated with therapeutic substance for a sustained release drug delivery system [2, 3]. Other components such as PLGA (poly(lactic-co-glycolic acid)) are also used to upgrade the bio-properties of the delivery system. In 1998, Wang has successfully produced agarose nanoparticle to encapsulate ovalbumin and PLGA agarose nanoparticles to trap insulin. Both nanoparticles show a sustained release of originally added proteins $[1,3]$. The nanoparticles need to target specifically therefore they usually contain components with high affinity to the target.

It is proved that one polymer glucan (found in many fungi, bacteria and plants) is comprised of linear repeated units of (1-3)- $\beta$-D-glucose [4]. Its gel can be created either through the neutralization or boiling of alkaline glucan solution above $55^{\circ} \mathrm{C}$. The use of glucan gel as drug delivery vehicle has been studied with the delivery of the ophylline, or albumin $[5,6]$. Another distinctive characteristic of glucan is its specific receptor on immunocytes called Dectin-1 (a receptor highly expressed on synovial immunocytes of RA patients) [4, 7]. The binding of glucan to Dectin-1 on Keratinocytes induces proliferation, migration and wound healing process both in vitro and in vivo experiments [8].

TNF- $\alpha$ is an essential cytokine that causes inflammation in RA. The use of TNF- $\alpha$ blocking agents is showing much useful in treatment of this disease $[9,10]$. There are several main biopharmaceuticals used to inhibit TNF- $\alpha$ such as Infliximab, Adalimumab and Etanercept [11, 12]. Among them, Etanercept (ETA) is a fusion protein comprising the extracellular domain of TNF receptor II (p75) and the Fc portion of IgG. Etanercept affinity to TNF- $\alpha$ is 10 to 20 fold stronger than that of adalimumab and infliximab. Clinical trials have shown that ETA exhibits a much less immunogenicity compared with Infliximab and Adalimumab [12]. However, effects of ETA administration are found short and inadequate. The two main reasons for the failure of this administration include: non-specific targeting of drug resulted in low efficiency and rapid drug clearance from the joint cavity due to its short bio half-life and direction of equilibrium with the systemic circulation. These disadvantages can cause serious side effects such as risk of infection due to numerous injections, local toxicity due to local high dose and some technical drawbacks related to the cost and time involved in the procedure and patient compliance [11-13].

It is necessary to develop a drug delivery system which is able to target specifically, reduce the adverse effects of high drug dose and remain moderately constant therapeutic level of the drug inside our body for a prolonged time without continuous administration. In addition, the drug delivery complex will be potential for enhancing the permeability and retention (EPR) effects of the vasculature to be concentrated mostly at tumors or inflammatory sites [9, 13]. 
For these reasons, we attempt to develop a polymeric matrix drug delivery system in comprising agarose, glucan and etanercept which capable of carrying, releasing drug in controlled level.

\section{Materials and methods}

\subsection{Materials}

Glucan was a gift from Professor Kazuo Sakurai, University of Kitakyushu, Faculty of Enviromental Engineering, Japan. Etanercept (trade name Enbrel) was purchased from Immunex Corp. (Thousand Oaks, CA, USA).

\subsection{Methods}

Preparation agarose-glucan gel complex carrying entanercept

Agarose powder (Bio Basic Canada Inc.) was dissolved in $1 \mathrm{ml}$ of pure water in a test tube by heating at $95{ }^{\circ} \mathrm{C}$ for $5 \mathrm{~min}$ in microwave, which produced a 3\% agarose solution. The test tube was covered with Paraffin to prevent water evaporation. The agarose solution was then cooled down to and maintained at $40{ }^{\circ} \mathrm{C}$ in another water bath. An amount of glucan powder, $15 \mathrm{mg}$, was dissolved in $1 \mathrm{ml}$ of $0.05 \mathrm{M} \mathrm{NaOH}$ solution.

Agarose and glucan solution were mixed thoroughly and then neutralized with $1 \mathrm{M} \mathrm{HCl}$ to reach pH 7 at $45^{\circ} \mathrm{C}$. Our purpose was to use ETA as a model protein drug. This ETA solution was added subsequently into the mixture to obtain the final concentration of the drug at $1 \mathrm{mg} / \mathrm{ml}$. The process of creating the agarose-glucan gel complex involves the emulsification of the aqueous phase which is the agarose, glucan and ETA mixture above and the organic phase including paraffin liquid and $3 \%$ of Span $80.1 \mathrm{ml}$ of the aqueous phase was transferred into $15 \mathrm{ml}$ of organic phase at $45^{\circ} \mathrm{C}$. The resultant w/o emulsion was then sonicated with an ultrasonic probe sonicator (Sonic Vibra cell) at $450 \mathrm{~W}$ for 10 seconds three times with at least 3 minutes break between each sonication [2, 14]. The final suspension was stored at $4{ }^{\circ} \mathrm{C}$ for at least 30 minutes before removing the organic phase. The organic phase was removed by centrifuging the suspension at $15000 \mathrm{rcf}$ for 10 minutes at $4{ }^{\circ} \mathrm{C}$. The pellets obtained were re-dispersed and re-centrifuged four times consecutively in $\mathrm{n}$-Hexane. The emulsion was then kept at $4{ }^{\circ} \mathrm{C}$ in a refrigerator for other analysis.

Morphological Study of agarose-glucan gel complex

The scanning electron microscopy (SEM) studies were conducted on a Nano SEM 450 instrument (Faculty of Physics, VNU University of Science, Vietnam National University, Hanoi). The morphology and size distribution of the nanogel were observed and recorded.

\section{Effect of $p H$ on the dissolution of nanoparticle complex}

HEPES buffer was prepared at a range of $\mathrm{pH}$ from 4 to $7.5(4 ; 4.6 ; 5.2 ; 5.7 ; 6.2 ; 6.5 ; 7$; and 7.5). $20 \mathrm{mg}$ of complex was used to test the dissolution of nanoparticle complex.

Drug loading efficiency and releasing in vitro determination

The complex after air-drying was placed in a tube containing $1 \mathrm{ml}$ of $1 \mathrm{X}$ PBS at $\mathrm{pH} 7.4$ and shaken at $100 \mathrm{rpm}$. The tube was centrifuged and the PBS solution was harvested and replaced with a new one every 24 hours until 80 hours to measure the concentration of drug protein using Bradford assay. $100 \mu \mathrm{l}$ of the obtained solution at each time point was diluted and added with appropriate amount of Bradford solution (Bio-rad) following the manufacturer's instruction. After 5 minutes of incubation, the absorbance can be read at $595 \mathrm{~nm}$ using a spectrophotometer (Biomate, UK).

\footnotetext{
Encapsulationefficiency $(\%)=$ $\frac{\text { Amount of Protein recovered }}{\text { Total amount of Protein used }} \times 100$
} 


\section{Results and discussion}

\subsection{Preparation of the TNF- $\alpha$ inhibitor - loaded agarose-glucan nanoparticle and their morphology}

Agarose gel, a kind of polysaccharide polymeric matrix with good compatibility, large capacity of absorption, porosity, hydrophilicity, was chosen as the matrix to capture ETA protein. In addition, glucan was also gelated to incorporate into the agarose matrix for the purpose of specific targeting the immunocytes, which highly express Dectin-1 receptor and accumulate a high number of immune cells at the joint of rheumatoid arthritis patients. Under the sonication to form nanoparticles, we would have nanogel complex containing agaroseglucan with each nanoparticle is matrix gel which captures ETA protein inside. This nanogel complex is expected to specifically target the synovial joint. With that idea, the nanogel complex is supposed to avoid ETA's high dose usage and non-specific targeting.

\subsubsection{Construction of nanogel components}

We have used the phase separation method following previous publications for preparation of polymeric nanospheres [1, 2, 3]. This organic phase separation method involves a polymerorganic solvent solution. Compounds (either water soluble or water insoluble) can be encapsulated in a polymer matrix made from agarose; in this study, apart from agarose, we added glucan for the specific targeting purpose, which also forms gel together with agarose. When encapsulating the protein drugs, the drugs are usually dissolved in an aqueous solution and then intergrated into the matrix gel. The mixture was then nano-emulsified in the organic solvent solution and the phase separation of the polymer solution took place through sonication, which led to micro/nanosphere/ formation.

Based on previous publications of Nuo Wang and Eun Ju Lee [1, 3, 14] and the short description in the materials and methods, we made up to $1 \mathrm{ml}$ of gel comprising $1.5 \%$ glucan and 3\% agarose. This agarose gel should be stable enough to encapsulate protein drug ETA before going to the organic separation phase. It is reported that the ratio of the organic phase to the aqueous phase should be high enough in order to reduce the possibility of aggregation and then fusion of the agarose-glucan droplets to a larger size [1-3]. In this experiment, the volume of paraffin liquid is important and it affects the nanogel size formation under sonicating condition. Therefore, we have tested different volumes of parafin liquid with $1 \mathrm{ml}$ of agarose-glucan gel and sonication speeds to ensure the appropriate size outcome of the nanogel. This volume must be adequate to disperse $1 \mathrm{ml}$ of agarose-glucan mixture under sonicating condition into nanospheres. Under the ultra sonication, we obtained a suspension liquid for further experiments.

\subsubsection{Size and size distribution}

With the purpose of creating nanoparticle complex as a drug delivery system, size and size distribution are important criteria. The particle size is related to the rate of drug releasing because of the variation of surface area for water molecules to diffuse into and for drug molecules to diffuse out of complex system. The different diffusion length is mostly based on the different nano sizes, which is also a dominating factor affecting drug release rate according to Fick's law of diffusion. We used the emulsion-converted to suspension in situ method which is strongly affected by the homogenization of the w/o emulsion and the concentration of agarose-glucan solution. The size of the agarose-glucan complex we have got depends on the size of the emulsion droplets in the w/o emulsion. The size of the agaroseglucan emulsion was controlled by the homogenization speed and homogenization length. When we used higher/ longer speed/ duration of the homogenization, we can get smaller droplet size in the emulsion, resulting in a smaller size of agarose-glucan nanogel. After each sonication, we checked the morphology of 
droplet to find the best sonication condition and duration time for making nanogel. Finally, after sonicating for 10 seconds at $450 \mathrm{~W}$ three times with at least 3 minutes break between each sonication; we obtained the morphology and size of nanogel as shown in Figure 1.

The nanoparticles's morphology was examined by using the Nova Nanosem 450 system. From the obtained SEM image (Figure 1A) (with high and low concentration), the nanoparticles were scattered and not aggregated.

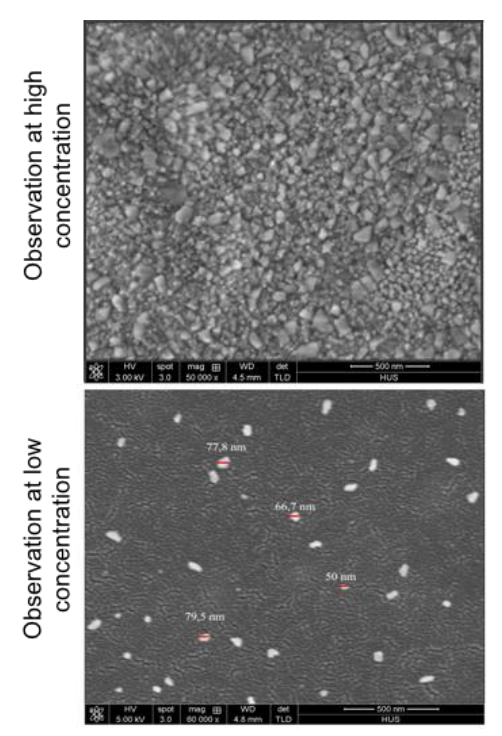

(A)

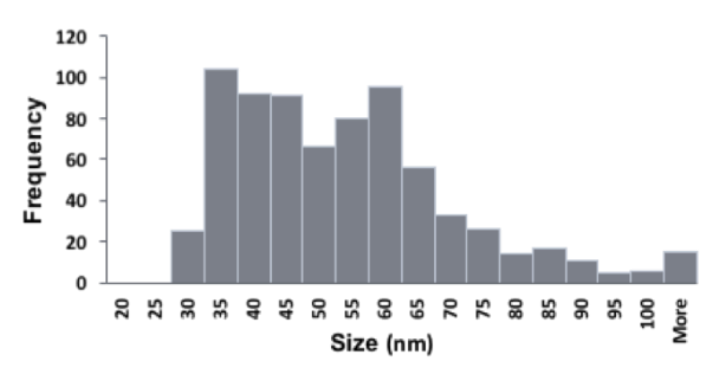

(B)

Figure 1. Morphology and Size distribution of nanogel complex. A) Scanning electron microscopy

(SEM) of nanogel at high and low concentration.

B) Size distribution of nanogel complex.
The surface of nanoparticle was not smooth. This was probably due to shrinkage characteristic of agarose hydrogel matrix during the drying process. This is a common morphology for other agarose hydrogel nanoparticles and similar characteristic was observed by Wang et al. 1997 [1, 3] on the nanoparticles made from agarose. Based on the image $J$ program, the distribution of nanoparticle sizes is recorded and shown in Figure 1B. The particle shape was variable but its size was mainly in an acceptable range of qualified nanoparticles (from 30 to $150 \mathrm{~nm}$, Figure 1B).

\subsection{Effect of $p H$ on the dissociation of nanoparticles}

We tested the dissociation of nanoparticle complex in the HEPES solution with a range of $\mathrm{pH}$ from 4 to 7.5. We found that $\mathrm{pH}$ can affect to the dissociation of nanoparticle complex. The nanoparticles can dissolve immediately at the $\mathrm{pH}$ from 5.2 to 6.2 (Figure 2).

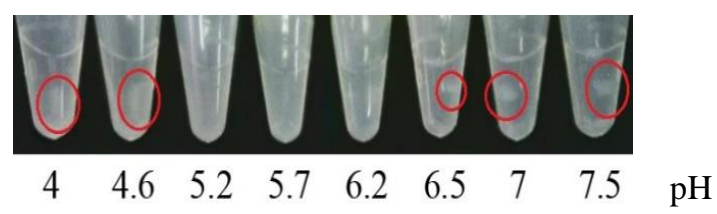

Figure 2. Effect of $\mathrm{pH}$ range on the dissociation of nanoparticle complex. The aggregates are circled in red.

However, at $\mathrm{pH}$ higher than 6.2, the nanoparticles formed aggregates and did not dissolve well. At lower $\mathrm{pH},(\mathrm{pH}<5.2)$, dissolution was decent, but some tiny particles were still visible (Figure 3). We can conclude that the $\mathrm{pH}$ does have an effect on the dissolution rate of the nanogel.

\subsection{Loading efficiency determination}

As described above, we added $1 \mathrm{mg}$ of ETA into $1 \mathrm{ml}$ of agarose-glucan gel. To assess the amount of protein drug encapsulated inside 1 $\mathrm{ml}$ of gel complex, we checked the protein ETA released from the gel at specific time points: 0 , 
24, 48, 72 and $80 \mathrm{hr}$. Before checking the protein release, we need to remove the paraffin liquid surrounding the nanoparticles by $n-$ hexane solution. As described in Materials and Methods, the gel complex was washed 4 to 5 times with n-hexane using a centrifuge. The gel was dissolved then incubated in a volume of water and slightly shaked at room temperature. All of the PBS solution (not containing nanogel particles) at each time point was taken out for protein quantity analysis using Bradford method. The concentration of protein was illustrated on Table 1.

The results of the protein release are shown on Table 1. The "Concentration of protein release $(\mu \mathrm{g} / \mathrm{ml})$ " of a specific time point is the sum of the protein concentration of this particular time point and the previous ones measured by Bradford method. Cumulative percentage of ETA released (\%) was calculated using the equation below:

$$
\begin{aligned}
& \text { Cumulative percentage of ETA release (\%) at } \boldsymbol{t} \text { hour } \\
& \qquad=\frac{\text { Concentration of protein release at } \boldsymbol{t} \text { hour }}{\text { Total protein encapsulated in } 1 \mathrm{ml} \text { nanogel }} \times 100
\end{aligned}
$$

As shown in table 1, ETA released from nanoparticle complex in a time-dependent manner.

Table 1. Cumulative percentage of protein released from $1 \mathrm{ml}$ of nanoparticle complex

\begin{tabular}{llllll}
\hline Time point $(\mathrm{h})$ & $\mathbf{0}$ & $\mathbf{2 4}$ & $\mathbf{4 8}$ & $\mathbf{7 2}$ & $\mathbf{8 0}$ \\
\hline Concentration of protein release $(\mu \mathrm{g} / \mathrm{ml})$ & 0 & 175.13 & 441.22 & 709.95 & 744.02 \\
Cumulative percentage of ETA release $(\%)$ & 0 & 17.5 & 44.1 & 71 & 74.4 \\
\hline
\end{tabular}

Figure 3 illustrates the time dependent release of ETA from nanoparticle complexes on Table 1. The result shows that protein concentration followed a linear equation $\mathrm{y}=$ $0.0131 \mathrm{x}-0.0284$ with $\mathrm{R}^{2}=0.9937$.
We also have calculated that the ETA released from complexes was 50 percent of ETA at 40.34 hours and the average drug encapsulation efficiency was $74.4 \%$. This data was repeated three times.

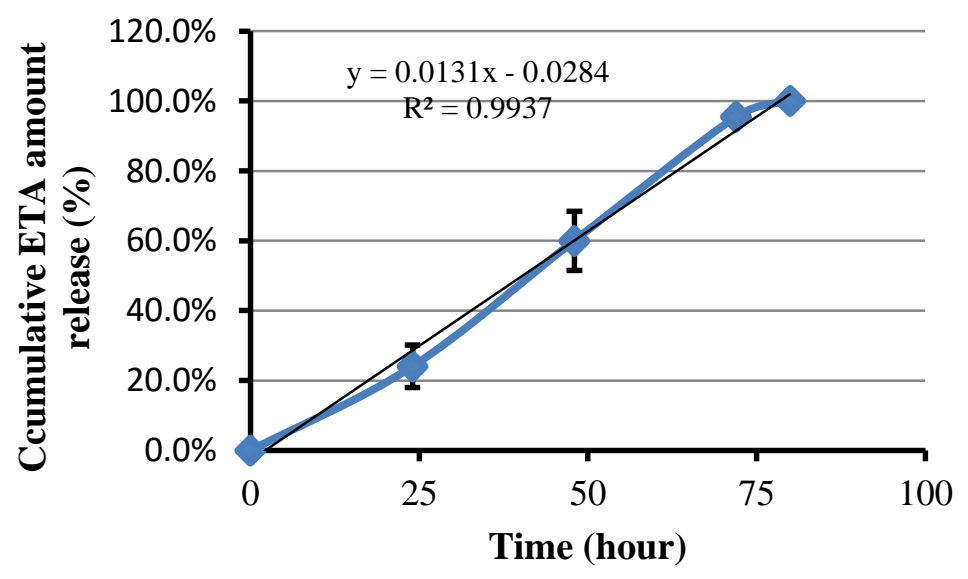

Figure 3. ETA released from nanogel complex in a time-dependent manner. 
The encapsulation of protein was stable enough because the loading efficiency were around 65 to $83 \%$ (data not shown) whenever repeated. This is a potential model for drug release control system. We expect it would be able to replace the conventional injection with high dose of ETA and specifically target at the immunocytes in the synovial fluid.

\section{Conclusion}

We have initially succeeded on making nanoparticles from agarose and glucan as a vehicle carrying TNF- $\alpha$ inhibitor, with the ratio of $3 \%$ agarose and $1.5 \%$ glucan gel for the encapsulation of $1 \mathrm{mg}$ of ETA. This is the first step on the purpose of creating a target drug delivery vehicle to gradually release ETA for further purpose of rheumatoid arthritis treatment. The SEM data confirmed the range of the nanoparticles's size was from 30 to 150 $\mathrm{nm}$. The complex is suitable to be a nanomaterial, however we need to optimize the process to obtain better size of the nanoparticle complexes $(\leq 100 \mathrm{~nm})$. The loading protein efficiency was up to $74.4 \%$ and the release of drug from the nanoparticle complexes was sustained and followed a linear equation $\mathrm{y}=$ $0.0131 \mathrm{x}-0.0284$, with $\mathrm{R}^{2}=0.99369$. We need to assess the release of encapsulated drug in vitro with neutralizing TNF- $\alpha$ experiments and evaluate the targeting ability of the complex on immunocyte cells. Further experiments are also needed to prove that this nanogel model is good candidate to be a targeting drug delivery system.

\section{Acknowledgements}

The research was funded by Vietnam National University to Pham Thi Thu Huong under project number: KLEPT16.01.

\section{References}

[1] N. Wang and X.S. Wu, Preparation and Characterization of Agarose Hydrogel Nanoparticles for Protein and Peptide Drug Delivery. Pharmaceutical Development and Technology 2(2) (1997) 135-142.

[2] Zhi-gang Jing, Chun-yu YANG, Chun-li YANG, Hailing Liu, Shuo Yang: Preparation of Homogeneous and Controllable Agarose Microbeads. Advances in Sciences and Engineering (2016).

[3] Nuo Wang, Xue Shen Wu, A novel approach to stabilization of protein drugs in poly(lactic-coglycolic acid) microspheres using agarose hydrogel. International Journal of Pharmaceutics 166(1) (1998) 1-14.

[4] P.R. Taylor, S.V. Tsoni, J.A. Willment, K.M. Dennehy, M. Rosas, H. Findon, K. Haynes, C. Steele, M. Botto, S. Gordon, Dectin-1 is required for beta-glucan recognition and control of fungal infection. Nature immunology 8(1) (2007) 31-38.

[5] M. Kanke, E. Tanabe, H. Katayama, Y. Koda, H. Yoshitomi, Application of curdlan to controlled drug delivery. III. Drug release from sustained release suppositories in vitro. Biological and Pharmaceutical Bulletin 18(8) (1995), 1154-1158.

[6] Beom Soo Kim, In Duck Jung, Jong Sik Kim, Jung-heon Lee, In Young Lee, Kyung Bok Lee, . Biotechnology letters 22(14) (2000), 1127-1130.

[7] E.H. Choy and G.S. Panayi, Cytokine pathways and joint inflammation in rheumatoid arthritis, New England Journal of Medicine 344(12) (2001) 907-916.

[8] C.Tetta, G. Camussi, V. Modena, C. Di Vittorio, C. Baglioni, Tumour necrosis factor in serum and synovial fluid of patients with active and severe rheumatoid arthritis. Annals of the Rheumatic Diseases, 49(9) (1990) 665-667.

[9] J. F. Fries, Current treatment paradigms in rheumatoid arthritis, Rheumatology 39, (2000) 30-35.

[10] I. H. Tarner, U. Müller-Ladner. Drug delivery systems for the treatment of rheumatoid arthritis. Expert opinion on drug delivery 5(9) (2008) 1027 1037.

[11] Chen Y.F., P. Jobanputra, P. Barton, S. Jowett, S. Bryan, W. Clark, A. Fry-Smith, A. Burls, A systematic review of the effectiveness of adalimumab, etanercept and infliximab for the treatment of rheumatoid arthritis in adults and an economic evaluation of their cost-effectiveness. 
Health Technol Assess 10(42) iii-iv, xi-xiii (2006), 1-229.

[12] P.S. Zehra Kaymakcalan, Sahana Bose, Comparisons of affinities, avidities, and complement activation of adalimumab, infliximab, and etanercept in binding to soluble andmembrane tumor necrosis factor, Clinical Immunology 2009.

[13] Y. Tanaka, Current concepts in the management of rheumatoid arthritis. Korean J Intern Med 31(2) (2016) 210-8.
[14] Eun Ju Lee, Joong Kon Park, Saeed A. Khan, Kwang-Hee Lim, Preparation of Agar Nanoparticles by W/O Emulsification.Journal of Chemical Engineering of Japan, 44(7) (2011) 502-508.

[15] Jaleh Varshosaz, Mohammad Reza Zaki, Mohsen Minaiyan, Jaafar Banoozadeh, Preparation, Optimization, and Screening of the Effect of Processing Variables on Agar Nanospheres Loaded with Bupropion $\mathrm{HCl}$ by a D-Optimal Design, BioMed Research International 2015, vol. 2015, Article ID 571816, 13 pages, 2015. https://doi.org/10.1155/2015/571816.

\section{Nghiên cứu tạo phức hệ vận chuyển agarose-glucan mang protein ức chế đặc hiệu yếu tố hoại tử u (TNF- $\alpha)$}

Nguyễn Bảo Ngọc ${ }^{1,2}$, Đỗ Thị Lý ${ }^{1,2}$, Esther Derouet $^{3}$, Nguyễn Hữu Tuấn Dũng ${ }^{1,2}$, NguyễnThanh Tùng ${ }^{1,2}$, Nguyễn Thị Phương Linh ${ }^{1,2}$, Nguyễn Hoàng Nam ${ }^{4}$, Nguyễn Minh Hiếu ${ }^{4}$, Nguyễn Đình Thắng ${ }^{1}$, Nguyễn Thị Vân Anh ${ }^{1}$, Phạm Thị Thu Hường ${ }^{1}$

${ }^{1}$ Phòng Thí nghiệm trọng điểm Công nghệ Enzym và Protein, Trưòng Đại học Khoa học Tụ nhiên, ĐHQGHN,334 Nguyến Trãi, Hà Nội, Việt Nam

${ }^{2}$ Khoa Sinh học, Truò̀ng Đại học Khoa học Tụ nhiên, ĐHQGHN, 334 Nguyễn Trãi, Hà Nội, Việt Nam

${ }^{3}$ Khoa Khoa học Vật liệu, Polytech Lille, Truờng Đại học Lille 1, Pháp

${ }^{4}$ Trung tâm Nghiên cúu Nano và Năng lương, Trường Đại học Khoa học Tự nhiên, ĐHQGHN, 334 Nguyễn Trãi, Hà Nội, Việt Nam

Tóm tắt: Mục đích của chúng tôi là phát triển và đặc trưng hoá hệ thống vận chuyển protein trong phức hệ agarose-glucan. Phức hệ này được tạo ra bằng cách sonic hỗn hợp các thành phần agaroseglucan và một protein trong chất lỏng paraffin với bộ vi xử lý Sonics Vibracell được điều chỉnh theo phương pháp Nuo Wang và cộng sự năm 1997. Chúng tôi sử dụng etanercept, một yếu tố hoại tử chống khối u-alpha (anti-TNF- $\alpha$ ) làm thuốc (protein) mô hình, được đóng gói thành công vào hệ thống phức hệ agarose-glucan. Protein này có khả năng trung hòa TNF- $\alpha$ đồng thời là một cytokine tiền viêm có vai trò quan trọng trong việc điều chỉnh đáp ứng viêm và làm trung gian tiến triển bệnh đặc biệt trong viêm khớp dạng thấp. Phức hệ agarose-glucan chúng tôi tạo được có sự phân bố kích thước từ 30 đến $150 \mathrm{~nm}$, phân tán tốt trong dải đệm $\mathrm{pH}$ từ 5,2 đến 6,2 , hiệu quả bao gói lên tới $74,4 \%$ và có khả năng giải phóng $50 \%$ protein sau 40,3 giờ. Nghiên cứu là tiền đề hình thành vật liệu nanogel mang thuốc hướng đích đặc hiệu trong điều trị viêm khớp dạng thấp.

Tì khóa: Agarose gel, agarose microspheres, glucan, emulsification cooling, rheumatoid arthritis. 